\title{
Sheehan's syndrome presenting as cardiac tamponade
}

\author{
Ankit Mittal, ${ }_{1}^{1}$ Animesh Ray, ${ }^{2}$ Ram Manohar Talupula, ${ }^{1}$ Rita Sood ${ }^{1}$
}

${ }^{1}$ Medicine, All India Institute of Medical Sciences, New Delhi, India

${ }^{2}$ Department of Medicine, All India Institute of Medical Sciences, New Delhi, India

Correspondence to Dr Ankit Mittal, mittalankit0505@gmail.com

Accepted 20 January 2018
Check for updates

To cite: Mittal A, Ray A Talupula RM, et al. BMJ Case Rep Published Online First: [please include Day Month Year]. doi:10.1136/bcr-2017 223129

\section{SUMMARY}

A 50-year-old woman presented with progressive dyspnoea and oedema with rapid deterioration over the last few days. Clinical examination revealed hypotension with cold clammy skin, raised jugular venous pressure and muffled heart sounds and was diagnosed to have cardiac tamponade, later confirmed on two-dimensional echocardiography. However, patient had bradycardia, and the other striking examination findings were coarse facies with pallor, madarosis, absent axillary and pubic hair and breast atrophy. Her blood sugar level was also low. Detailed history revealed an episode of postpartum haemorrhage with lactation failure and early menopause. Pericardiocentesis was done with a pig-tail catheter. Hormone profile and MRI brain confirmed the diagnosis of Sheehan's syndrome. Patient improved on treatment with thyroxine and hydrocortisone supplementation and was discharged with education about stress dosing.

\section{BACKGROUND}

Cardiac tamponade is a medical emergency as it can lead to life-threatening obstructive shock. Most common causes of cardiac tamponade are neoplastic diseases, blunt chest trauma, renal failure, infections (tuberculosis, etc), autoimmune diseases or idiopathic pericarditis. ${ }^{12}$ Pericardial effusion in primary hypothyroidism is well recognised but is extremely rare in secondary hypothyroidism; tamponade as a presenting feature is rarer with only a handful of case reports. ${ }^{3-5}$ However, it is important to keep it in our list of differentials, especially when a patient in tamponade presents with bradycardia. ${ }^{6}$

\section{CASE PRESENTATION}

A 50-year-old female patient with no other known comorbidities, from a rural background, presented with gradually progressive swelling of the lower limbs associated with gradually progressive shortness of breath and extreme lethargy since the last 3 months and rapid deterioration over the last few days. On examination, she was hypotensive (blood pressure: $80 / 60 \mathrm{~mm} \mathrm{Hg}$ ) with raised jugular venous pressure, muffled heart sounds and a pulsus paradoxus of $12 \mathrm{~mm} \mathrm{Hg}$. ECG showed low-voltage complexes, and the chest X-ray showed increased cardiothoracic ratio (figure 1). An urgent echocardiography was done which revealed a large pericardial effusion (circumferential thickness $2.3 \mathrm{~cm}$ ) with right atrial and right ventricular diastolic collapse and swinging motion of the heart suggestive of an impending tamponade. Other striking examination findings were coarse facies with pallor, madarosis, absent axillary and pubic hair and breast atrophy. Despite being hypotensive, the patient had bradycardia. Her Random Blood Sugar (RBS) was $68 \mathrm{mg}$ / dL.

On probing, her son gave the history of change in quality of voice since around 10 years and also stated that she had become extremely lethargic over the same period. He also gave history that, during her last child birth, around 12 years ago, there was significant bleeding after delivery, and she had required prolonged hospitalisation and blood transfusions following which she had failed to lactate and had developed menopause by the age of around 40 years.

With the clinical suspicion of Sheehan's syndrome, a hormone profile was sent prior to initiation of supplementation. Since she had to be started on hydrocortisone, a Synacthen test could not be done. Reports revealed low pituitary hormones (table 1 ): T3 $0.35 \mathrm{ng} / \mathrm{mL}$ (N: $0.58-1.59 \mathrm{ng} / \mathrm{mL}), \mathrm{T} 44.75 \mu \mathrm{g} /$ $\mathrm{mL}(\mathrm{N}: 4.87-11.72 \mu \mathrm{g} / \mathrm{mL})$, thyroid stimulating hormone $1.166 \mu \mathrm{IU} / \mathrm{mL}$ (N: 0.35-4.94), luteinising hormone (LH) $3 \mathrm{mIU} / \mathrm{mL}(\mathrm{N}: 5.16-61.9 \mathrm{mIU} /$ $\mathrm{mL}$ in postmenopausal women not on hormone replacement therapy), follicle-stimulating hormone (FSH) $6.96 \mathrm{mIU} / \mathrm{ml}(\mathrm{N}: 26.7-133 \mathrm{mIU} / \mathrm{ml}$ in post menopausal women not on hormone replacement therapy), prolactin $2.55 \mathrm{ng} / \mathrm{mL}$ (N: $5.18-26.53 \mathrm{ng}$ /

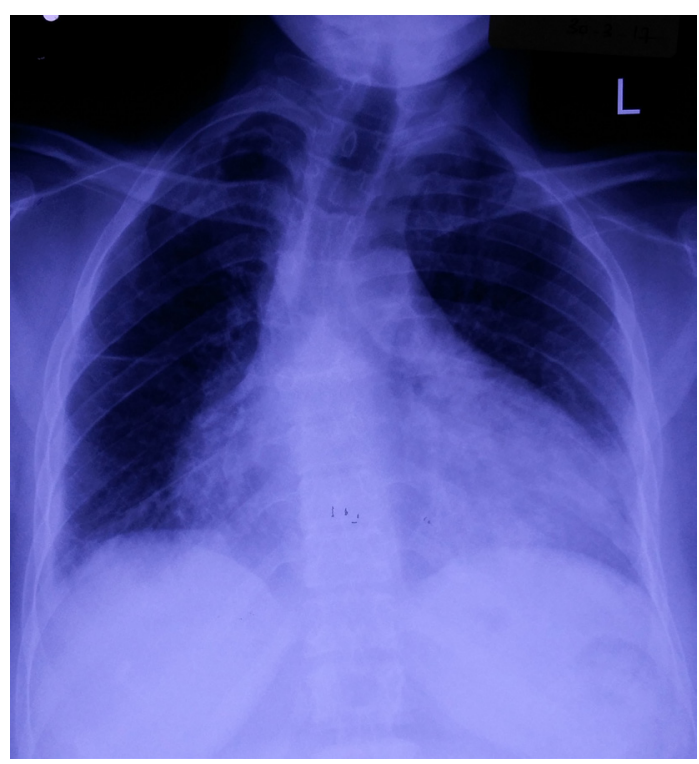

Figure 1 Skiagram of the chest showing a markedly enlarged cardiothoracic ratio. 


\begin{tabular}{lll}
\hline \multicolumn{2}{l}{ Table 1} & Hormone profile \\
\hline Test & Value & Reference \\
\hline T3 & $0.35 \mathrm{ng} / \mathrm{mL}$ & $0.58-1.59$ \\
T4 & $4.75 \mu \mathrm{g} / \mathrm{dL}$ & $4.87-11.72$ \\
TSH & $1.166 \mu \mathrm{lU} / \mathrm{mL}$ & $0.35-4.94$ \\
LH & $3.00 \mathrm{mlU} / \mathrm{mL}$ & $5.16-61.9^{*}$ \\
FSH & $6.96 \mathrm{mlU} / \mathrm{mL}$ & $26.7-133^{*}$ \\
\hline PRL & $2.55 \mathrm{ng} / \mathrm{mL}$ & $5.18-26.53$ \\
ACTH & $0.63 \mathrm{pmol} / \mathrm{L}$ & $1.11-6$ \\
\hline Cortisol & $4.9 \mu \mathrm{g} / \mathrm{dL}$ & $>30 \dagger$ \\
\hline
\end{tabular}

*Postmenopausal women not on hormone replacement therapy.

tStress cortisol levels.

ACTH, adrenocorticotropic hormone; FSH, follicle-stimulating hormone; LH, luteinising hormone; PRL, prolactin; TSH, thyroid-stimulating hormone.

$\mathrm{mL}$ ), ACTH $0.63 \mathrm{pmol} / \mathrm{L}$ (N: 1.11-6 pmol/L), cortisol $4.9 \mu \mathrm{g} /$ $\mathrm{dL}(\mathrm{N}:>30$ in physiological stress). Since tuberculosis is a very common cause of pericardial effusion in India, it was ruled out with relevant pericardial fluid analysis (table 2): nil cells, normal biochemistry, negative Adenosine Deaminase (ADA), negative Acid-fast Bacilli (AFB) staining and a negative Gene Xpert. Gram stain and culture for bacteria were also negative.

An MRI of the brain was done for confirmation of diagnosis which showed a partially empty sella consistent with the diagnosis of Sheehan's syndrome (figures 2 and 3).

\section{TREATMENT}

Pig-tail catheter for pericardiocentesis was placed, and $400 \mathrm{~mL}$ of straw-colour fluid was drained. Initially, she also required inotropic support to maintain a mean arterial pressure above $65 \mathrm{~mm} \mathrm{Hg}$.

She was started on thyroxine $(50 \mu \mathrm{g}$ on day 1 followed by $100 \mu \mathrm{g}$ daily) adjusted for her weight and was given intravenous hydrocortisone until she stabilised and then shifted to oral hydrocortisone $15 \mathrm{mg}$ in the morning and $10 \mathrm{mg}$ in the evening.

\section{OUTCOME AND FOLLOW-UP}

Patient responded well to the treatment with progressive reduction in the pericardial drain, and inotropic support was gradually tapered off. The drain was removed after 10 days.

Follow-up at 3 months: T3, $1.19 \mathrm{ng} / \mathrm{mL}(0.58-1.59)$; T4, $7.12 \mu \mathrm{g} / \mathrm{dL}$ (4.87-11.72); thyroid-stimulating hormone (TSH), $0.394(0.35-4.94)$.

\begin{tabular}{|c|c|}
\hline Test name & Result \\
\hline TLC/DLC & 10/All lymphocytes \\
\hline RBC & None \\
\hline Glucose & $104 \mathrm{mg} / \mathrm{dL}$ \\
\hline Protein & $5.2 \mathrm{~g} / \mathrm{dL}$ \\
\hline Albumin & $3.0 \mathrm{~g} / \mathrm{dL}$ \\
\hline ADA & 12 \\
\hline Gram stain & No pus cells, bacilli \\
\hline $\mathrm{KOH}$ & Negative for fungi \\
\hline Culture result & Negative for bacteria and fungi \\
\hline ZN staining & Negative for acid fast bacilli \\
\hline Gene Xpert & MTB not detected \\
\hline
\end{tabular}

DLC: Differential Leucocyte Count KOH: Potassium Hydroxide Mount RBC: Red Blood Cells TLC: Total Leucocyte Count MTB: Mycobacterium Tuberculosis ZN: Ziehl-Neelsen

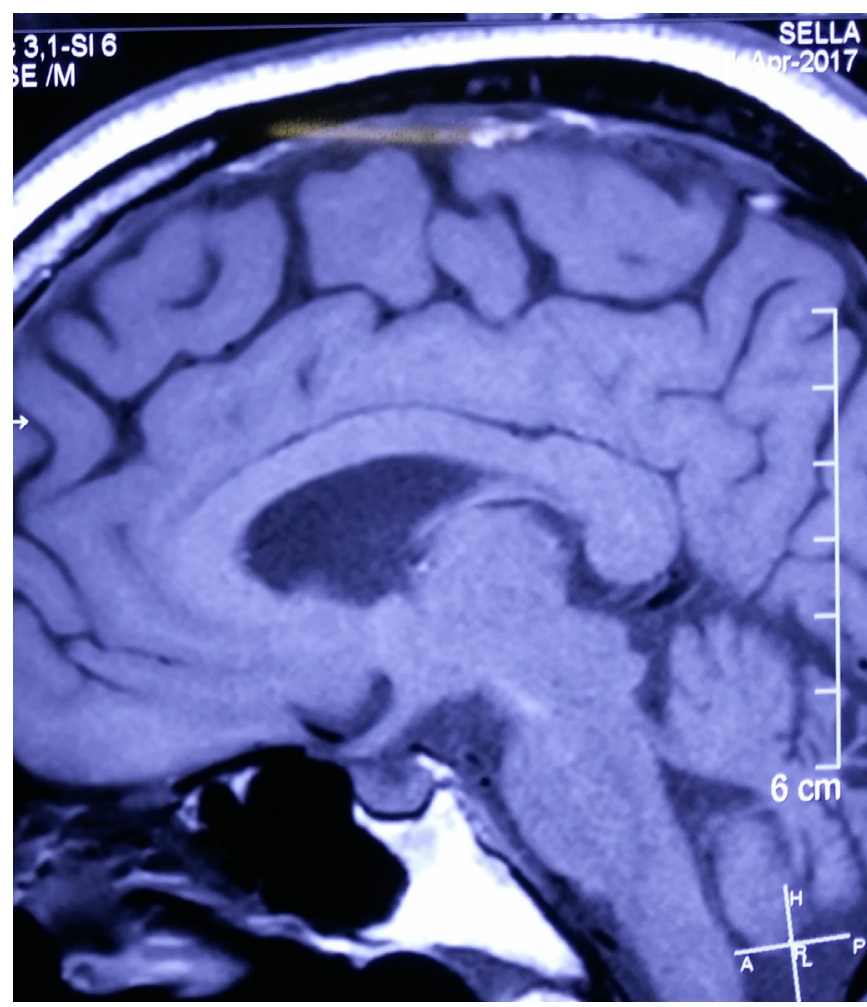

Figure 2 T1-weighted image of the brain (sagittal section) showing a partially empty sella.

\section{DISCUSSION}

Postpartum anterior pituitary necrosis or Sheehan's syndrome corresponds to ischaemic necrosis of the anterior pituitary secondary to postpartum haemorrhage, resulting in varying degree of pituitary insufficiency. It was first described in 1937,

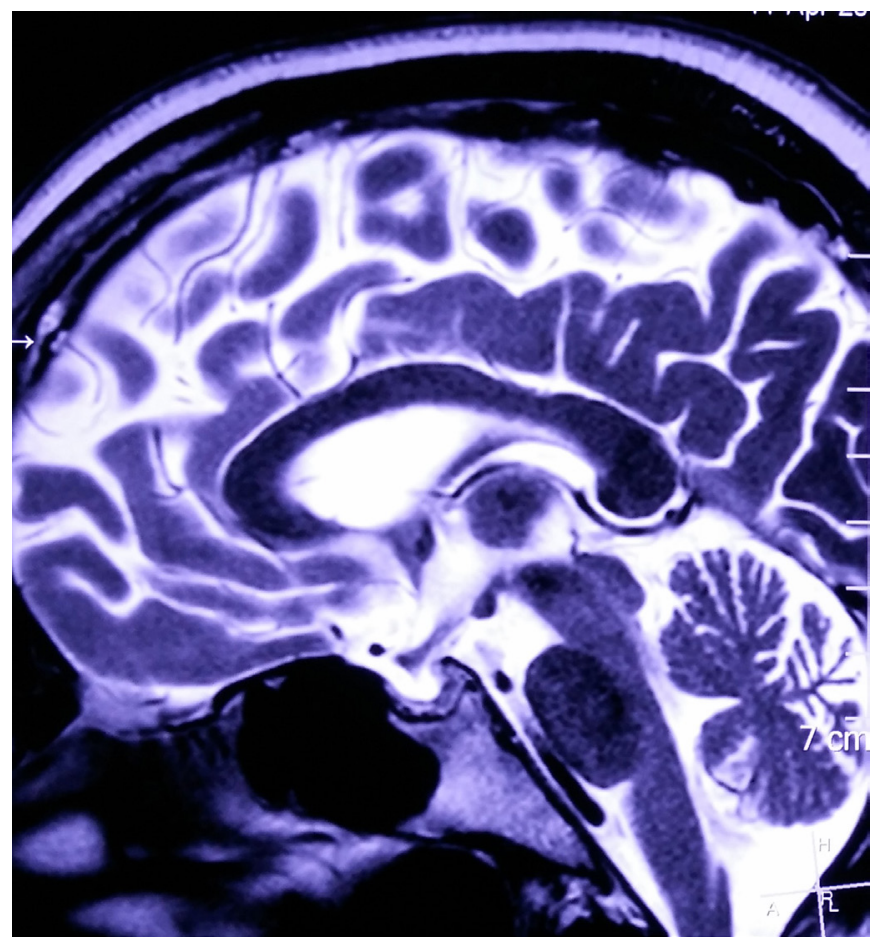

Figure 3 T2-weighted image of the brain (sagittal section) showing a partially empty sella. 
and since then, its occurrence has been steadily declining as a consequence of better maternal care throughout pregnancy and during delivery. ${ }^{7}$ However, it might still be an under-recognised problem in the rural settings, especially in the developing countries, like in the case described here. Coexistence of other pituitary hormones deficiency may mask the effect of hypothyroidism, for example, hot flashes secondary to hypogonadism may mask cold intolerance or weight loss due to adrenal insufficiency may counterbalance the weight gain due to hypothyroidism. Patients either remain unaware of the subtle symptoms like asthenia, adynamia, decrease in axillary and pubic hair and impairment in cognitive functions and so on, or do not understand the need to seek medical attention even for symptoms like breastfeeding failure, failure of resumption of menses and so on. They present mostly with features of overt hypothyroidism or with adrenal insufficiency (fatigue, weight loss, hypoglycaemia, hyponatraemia). ${ }^{8}$ Proper history and examination can help to clinch the diagnosis. However, for a Sheehan to have cardiac tamponade as the primary presentation is very rare. The effusion is presumably due to the central hypothyroidism and is a slowly accumulating one, and therefore a large amount of fluid needs to accumulate before tamponade occurs. Improvement following hormone replacement further points towards endocrinological aetiology of effusion. However, since the response takes time and the effusion is almost always large, pericardiocentesis with a catheter is necessary in most cases. ${ }^{5}$ Bradycardia in cardiac tamponade is a very strong marker for hypothyroid aetiology, and a clinician might want to rule out Sheehan's syndrome as the cause in a postmenopausal woman, at least clinically. ${ }^{46}$

Proper history and examination will almost always give us a diagnosis of Sheehan's syndrome. Lymphocytic hypophysitis is an important differential as it can also develop post partum and can cause pituitary atrophy over years. It is important to rule out pituitary apoplexy secondary to pituitary adenoma as surgical resection is the treatment of choice for this. A hormone profile can be obtained for fT3, fT4, TSH, LH, FSH, prolactin, growth hormone (GH), ACTH and cortisol levels to aid the diagnosis. GH deficiency is the first to occur in Sheehan's syndrome, however, is not necessary for the diagnosis and in the majority of patients will not change the management as the modest increase in body mass index with GH supplementation does not justify the need for daily injections and high cost, especially in a financially constrained setting. Similarly, serum oestradiol levels, even though will help in reinforcing the diagnosis, it may not change the management unless the patient has symptoms like hot flushes and so on which might warrant replacement. An unequivocally low basal ACTH level with a low-serum cortisol level precludes the need for a Synacthen test. MRI brain might show a normal sized, partially or a completely empty sella. The diagnosis can be made using either the criteria by Diri $e t a l^{9}$ or the revised criteria by Karaca et al..$^{10}$

Management of the Sheehan's syndrome is primarily by hormone replacement, with the drug of choice being oral hydrocortisone and levothyroxine. Patient should be educated about doubling the dose of hydrocortisone during periods of illness. ${ }^{8}$

\section{Learning points}

In patients of cardiac tamponade, bradycardia should point towards a concurrent hypothyroid status.

- Sheehan's Syndrome should be excluded with appropriate history and clinical examination in a menopausal woman with Hypothyroidism

- Concurrent hypopituitarism may mask the features of hypothyroidism.

Acknowledgements Dr Venkatesh Vaithiyam, Dr Shiva Balan and Dr Siddharth Jain.

Contributors All four authors were directly involved in patient care. AM and RMT: junior resident in-charge. AR: assistant professor in charge. RS: unit head and professor in charge. All four authors contributed to the writing. AM prepared the first draft and reviewed the literature. RMT helped with images and review. AR and RS helped in improving the layout and finalising the draft.

Competing interests None declared.

\section{Patient consent Obtained.}

Provenance and peer review Not commissioned; externally peer reviewed.

(c) BMJ Publishing Group Ltd (unless otherwise stated in the text of the article) 2018. All rights reserved. No commercial use is permitted unless otherwise expressly granted.

\section{REFERENCES}

1 Richardson L. Cardiac tamponade. JAAPA 2014;27:50-1.

2 Bodson L, Bouferrache K, Vieillard-Baron A. Cardiac tamponade. Curr Opin Crit Care 2011;17:416-24.

3 Sahin I, Taskapan H, Yildiz R, et al. Cardiac tamponade as initial presentation of Sheehan's syndrome. Int J Cardiol 2004;94:129-30.

4 Ekka M, Ali I, Aggarwal P, et al. Cardiac tamponade as initial presenting feature of primary hypothyroidism in the ED. Am J Emerg Med 2014;32:683.e1-3.

5 Tahir MZ. Cardiac tamponade in hypothyroidism due to Sheehan's syndrome. J Pak Med Assoc 1992:42:249-51.

6 Bajaj R, Mehrzad R, Singh K, et al. Cardiac tamponade in hypothyroidism. Case Rep Child Meml Hosp Chic 2014. doi:10.1136/bcr-2014-204076. [Epub ahead of print 26 May 2014].

7 Bouznad N, Mghari GE, Hattaoui ME, et al. Révélations cardiaques atypiques rares du syndrome de Sheehan : à propos de trois cas. Ann Cardiol Angeiol 2017;66:239-42.

8 Kilicli F, Dokmetas HS, Acibucu F. Sheehan's syndrome. Gynecol Endocrinol 2013;29:292-5

9 Diri H, Karaca Z, Tanriverdi F, et al. Sheehan's syndrome: new insights into an old disease. Endocrine 2016;51:22-31.

10 Karaca Z, Laway BA, Dokmetas HS, et al. Sheehan syndrome. Nat Rev Dis Primers 2016;2:16092

Copyright 2018 BMJ Publishing Group. All rights reserved. For permission to reuse any of this content visit

http://group.bmj.com/group/rights-licensing/permissions

BMJ Case Report Fellows may re-use this article for personal use and teaching without any further permission.

Become a Fellow of BMJ Case Reports today and you can:

- Submit as many cases as you like

- Enjoy fast sympathetic peer review and rapid publication of accepted articles

- Access all the published articles

Re-use any of the published material for personal use and teaching without further permission

For information on Institutional Fellowships contact consortiasales@bmjgroup.com

Visit casereports.bmj.com for more articles like this and to become a Fellow 